\title{
Robert Skobelski
}

https://orcid.org/0000-0001-7034-611X

Instytut Historii Uniwersytetu Zielonogórskiego

\section{„Na pierwszej linii drogowcy, kolejarze, energetycy i wojsko"1. Tak zwana zima stulecia 1979 roku na przykładzie Ziemi Lubuskiej}

\begin{abstract}
Zarys treści: Artykuł dotyczy zimy stulecia 1979 r., której skutki przedstawiono na przykładzie Ziemi Lubuskiej w szerokim kontekście ogólnopolskim. Warunki w kraju i tytułowym regionie zostały przeanalizowane w różnych dziedzinach życia gospodarczego i społecznego: komunikacji i transporcie, systemie energetycznym i ciepłownictwie, handlu i zaopatrzeniu ludności, a także w odniesieniu do problemów przemysłu i rolnictwa. Zaakcentowano nieporadność ówczesnych władz, wynikającą ze słabości systemowych, czego efektem były licznie zaniedbania i chaos organizacyjny.

Abstract: The article deals with the effects of the so-called 'Winter of the Century' of 1979 on the example of the Lubusz Land in a broad national context. The conditions in the country and the region were analysed in various domains of economic and social life: transport and communication, the energy and heating systems, trade and supply, and also in relation to industrial and agricultural problems. The then authorities' incompetence was emphasised as a result of political system weaknesses, leading to numerous failures and organisational chaos.
\end{abstract}

Słowa kluczowe: zima stulecia, Ziemia Lubuska, energetyka, transport, ciepłownictwo, przemysł, rolnictwo

Keywords: Winter of the Century, Lubusz Land, power industry, transport, heat engineering, industry, agriculture

\section{Wprowadzenie}

Na miano zimy stulecia w okresie powojennym zasługuje nie tylko ta z roku 1979. Potężne mrozy i ponadprzeciętne opady śniegu, paraliżujące gospodarkę i życie codzienne ludzi, zdarzały się w kraju już wcześniej. Takie warunki spełniała na pewno ostra zima z lat 1946/1947, której charakter wyznaczały przede wszystkim

\footnotetext{
1 Podtytuł materiału zamieszczonego w „Gazecie Lubuskiej” z 3 I 1979, nr 2.
} 
drastyczne spadki temperatury, odnotowywane już od połowy listopada. Podobnie groźny przebieg miała zima 1962/1963 r., kiedy całą Polskę, zwłaszcza regiony południowe, przez ponad trzy miesiące nawiedzały fale śnieżyc, a mrozy przekraczały nieraz $-30^{\circ} \mathrm{C}$. W obu przypadkach śnieżno-lodowy żywioł dotknął również wiele innych państw europejskich ${ }^{2}$.

Zima stulecia 1978/1979 r. przypadła na schyłek władzy Edwarda Gierka w PRL i spotęgowała narastający już od dłuższego czasu kryzys ekonomiczny. Wszystkie wady scentralizowanego systemu kierowania gospodarką i całym państwem uwydatniła więc wówczas pogoda, dołączając, oczywiście nie pierwszy raz, do wrogów ustroju socjalistycznego. Biorąc pod uwagę rozmiar trudności, jakie śnieg i mróz sprawiły w pierwszych tygodniach 1979 r., chyba bez większej przesady można postawić tezę, że przybliżyło to kres rządów ekipy gierkowskiej, który nastąpił niespełna dwa lata później.

Tymczasem nieomal do końca roku 1978 nic nie zapowiadało zimowego kataklizmu. Utrzymująca się długo łagodna aura i deszczowe święta Bożego Narodzenia zwiastowały raczej „lekką” zimę. Jednak 29 grudnia pojawiły się silne mrozy, a następnie intensywne opady śniegu, narastające od północy kraju. 31 grudnia doszło do zupełnego załamania pogody - temperatura w niektórych miejscach spadła poniżej $-20^{\circ} \mathrm{C}$, jak choćby w Warszawie, w Suwałkach zaś 1 stycznia odnotowano nawet $-26^{\circ} \mathrm{C}$. Porywy zachodniego wiatru, przekraczające 50 $\mathrm{km} / \mathrm{h}$, wzniecały zawieje i zamiecie śnieżne, ograniczające widoczność niemal do zera i tworzące olbrzymie zaspy. Cała Polska, dosłownie, stanęła na prawie dwa miesiące, choć najgorszy był pierwszy tydzień stycznia 1979 r. Paraliż dotknął większość branż przemysłu, transport, komunikację kolejową, drogową, tramwajową oraz lotniczą; wstrzymano żeglugę śródlądową; w zespołach portowych, zwłaszcza Gdańska i Gdyni, unieruchomione zostały dziesiątki statków³; mnożyły się mniejsze i większe awarie w elektrowniach; w licznych osiedlach mieszkaniowych wyłączano centralne ogrzewanie; narastały problemy z dostawami gazu. Na początku stycznia miasta wyglądały wręcz na wymarłe, szczególnie gdy zredukowano oświetlenie ulic. Do niektórych miejscowości w kraju udawało się

2 Zob.: D. Jarosz, Pierwsza powojenna „zima stulecia” w Polsce. Wybrane konteksty, w: Od powietrza, głodu, ognia $i$ wojny... Klęski elementarne na przestrzeni wieków, red. T. Głowiński, E. Kościk, Wrocław 2013, s. 215 i nn.; H. Wilk, Zima stulecia - zmagania z żywiołem 1962/1963, w: ibidem, s. $309 \mathrm{nn}$.

${ }^{3}$ W Gdańsku zarówno w porcie, jak i na redzie na początku stycznia utknęły 54 statki. Warunki nawigacyjne pogorszyły się na tyle, że uniemożliwiały wprowadzanie jednostek do portu. 3 stycznia załadunki i wyładunki prowadzono tutaj na zaledwie czterech statkach. W Porcie Północnym nastąpiła awaria urządzeń do rozmrażania wagonów z węglem. Z kolei w Gdyni śnieg, wiatr i mróz zaskoczył 59 statków (obsługiwano tylko dwie jednostki). W tym czasie lepsza sytuacja panowała natomiast w zespole portowym Szczecin - Świnoujście (choć i tu warunki szybko się pogarszały), gdzie z 84 statków 3 stycznia obsługiwano 36, AAN, KC PZPR, sygn. XII-4260, Informacja o sytuacji w dniu 3 I 1979 r. godz. 18.00, Warszawa, 3 I 1979, b.pag. 
dotrzeć dopiero po kilkunastu dniach, do wielu zaś sklepów, zwłaszcza wiejskich, nie dowieziono nawet podstawowych towarów spożywczych. Zawieszono zajęcia w szkołach i na wyższych uczelniach, ograniczono pracę żłobków i przedszkoli, zamknięto placówki kultury i obiekty sportowe, a telewizja skróciła czas nadawania programu. W województwach bydgoskim, gdańskim, legnickim, poznańskim i toruńskim ogłoszono stan klęski żywiołowej. Wstrzymano ruch turystyczny z Polski do innych krajów. Decyzją Ministerstwa Handlu Wewnętrznego i Usług przedłużono termin realizacji kartek na cukier do 13 stycznia. Sytuację potęgował fakt, że fala mrozów i śniegi zaskoczyły kraj w momencie świątecznego rozluźnienia - od przedsylwestrowej soboty po poniedziałkowy Nowy Rok. Dochodził do tego zamęt organizacyjny oraz niedostatek sprzętu (także jego poziom techniczny), jakim dysponowały służby odpowiedzialne za przygotowanie państwa do zimy ${ }^{4}$. Pierwsze dni 1979 r. nie kończyły pogodowych perturbacji. W lutym, po kolejnym ataku śniegu i mrozu, sytuacja powtórzyła się, choć w nieco mniejszej skali. W najgorszej sytuacji znalazły się wówczas tereny środkowej i wschodniej Polski, ale i w regionach zachodnich także wystąpiły problemy ${ }^{5}$.

$\mathrm{Na}$ Ziemi Lubuskiej ${ }^{6}$, podobnie jak i w całym kraju, śnieżycom i zamieciom towarzyszył nagły spadek temperatury - 31 grudnia w wielu miejscach słupki rtęci pokazały $-20^{\circ} \mathrm{C}$. Jeszcze tego samego dnia w Gorzowskiem i Zielonogórskiem, wzorem innych województw, powołano specjalne „sztaby zimowe”, którymi kierowali wojewodowie - Stanisław Nowak i Jan Lembas. Ich rola polegała na organizowaniu i koncentrowaniu sił i środków służb, a także przedsiębiorstw, na odśnieżaniu dróg oraz przywracaniu sprawnej pracy komunikacji i transportu. Równie istotnym zadaniem było zapewnienie ludności wystarczających dostaw podstawowych artykułów żywnościowych i opału dla miejscowości, w których mogły wystąpić większe braki w kotłowniach? ${ }^{7}$. Cały czas do mieszkańców,

${ }^{4}$ Zob.: G. Sieczkowski, Zima stulecia. Portret pamięciowy kataklizmu, Warszawa 2017, s. 187-188; M. Zaremba, Zimno, ciepło, goraco, w: Dekada Gierka. Polska i Polacy między Grudniem '70 a Sierpniem '80, „Polityka. Pomocnik Historyczny” 14/2010, s. 136-137; M. Wesołowska, Próba zimna, „Polityka” 6 I 1979, nr 1, s. 3; Komunikat Rady Ministrów. Zwalczanie następstw ostrego ataku zimy, „Gazeta Lubuska” 2 I 1979, nr 1; AAN, KC PZPR, sygn. XII-4260, Informacja o sytuacji w dniu 3 I 1979 r. godz. 18.00, Warszawa, 3 I 1979, b.pag.; 40. rocznica „zimy stulecia”. Jak wyglądałaby powtórka $z$ lodowatego horroru $w$ dzisiejszych czasach?, https://www.twojapogoda. pl/wiadomosc/2018-12-27/40-rocznica-zimy-stulecia-jak-wygladalaby-powtorka-z-lodowategohorroru-w-dzisiejszych-czasach/ (dostęp: 11 X 2020).

5 AAN, KC PZPR, sygn. XII-3814, Informacja nr III/61/79. Warszawa, 1 lutego 1979 r. Przezwyciężanie skutków opadów śniegu, b.pag.; Zima nie kapituluje, „Gazeta Lubuska” 15 II 1979, nr 35.

${ }^{6}$ W niniejszym tekście Ziemia Lubuska jest rozumiana jako województwa gorzowskie i zielonogórskie, utworzone w ramach nowego podziału administracyjnego państwa 1 czerwca 1975 r. (Dz.U. PRL z 1975, nr 16, poz. 91, Ustawa z dnia 28 maja 1975 r. o dwustopniowym podziale administracyjnym Państwa oraz o zmianie ustawy o radach narodowych).

7 AAN, KC PZPR, sygn. XII-3814, Informacja nr III/6/79, Warszawa, 3 I 1979, Usuwanie skutków mrozów i opadów śniegu, b.pag.; APZG, Komitet Wojewódzki PZPR (dalej: KW PZPR), 
zakładów pracy i instytucji kierowano apele o maksymalną oszczędność energii cieplnej i elektrycznej (hasło ,jednej żarówki w każdym mieszkaniu”) oraz wyłączanie wszystkich zbędnych urządzeń. Administrację mieszkaniową zobowiązano do natychmiastowego przeglądu szczelności piwnic, klatek schodowych oraz zabezpieczenia wybitych okien. Na bieżąco o sytuacji związanej z atakiem zimy i usuwaniem jej skutków w Zielonogórskiem i Gorzowskiem informowała rozgłośnia Polskiego Radia w Zielonej Górze ${ }^{8}$.

\section{Komunikacja i transport}

System komunikacyjny państwa okazał się zupełnie nieprzygotowany na tak ciężkie warunki pogodowe. Dla PKP - jak pisze Marcin Zaremba - były to najgorsze dni od czasów wojny i powojennych migracji. 1 stycznia, dla ułatwienia przewozów towarowych, w całym kraju odwołano aż 800 pociągów, jednak nie przyniosło to odczuwalnej poprawy sytuacjị. Jedynie w Bydgoskiem utknęło 60 elektrowozów i lokomotyw spalinowych, w województwie legnickim unieruchomione było $80 \%$ całego taboru szynowego, w okolicach Gdańska zaś na pewien czas w ogóle zawieszono ruch kolejowy. Wprawdzie 3 stycznia główne szlaki i tory stacyjne były przejezdne, jednak trudna sytuacja utrzymywała się w dalszym ciągu na stacjach rozrządowych podległych kilku dyrekcjom regionalnym PKP - wschodniej, północnej, centralnej i dolnośląskiej. Zmobilizowani pracownicy kolei, wspomagani przez wojsko, a często także przez załogi unieruchomionych przedsiębiorstw, robili co mogli dla udrożnienia najważniejszych linii. Jednak z największymi zaspami (nawet trzymetrowymi!) zwykłe pługi nie zawsze sobie radziły ${ }^{10}$. W takich wypadkach - jak wspominał I sekretarz KC Edward Gierek - na głównych szlakach, w celu oczyszczenia torów, kolejarze instalowali na platformach lotnicze silniki odrzutowe i uruchamiali je tak, aby

sygn. 243, Protokół nr 1 wspólnego posiedzenia Egzekutywy Komitetu Wojewódzkiego PZPR i Prezydium WRN w Zielonej Górze z dnia 12 I 1979, k. 4; Ziemia Lubuska w okowach zimy, „Gazeta Lubuska” 3 I 1979, nr 2.

8 Ziemia Lubuska w okowach zimy, „Gazeta Lubuska” 3 I 1979, nr 2; Skuteczność i ofiarność - czynniki decydujące w zmaganiach $z$ ofensywa zimy na Ziemi Lubuskiej, „Gazeta Lubuska” 4 I 1979, nr 3.

9 M. Zaremba, Wywrotowa zima, „Polityka” 17 I 2009, nr 3, s. 61; B. Kruk, „Pamiętam był ogromny mróz...". Zimowe zmagania Polskich Kolei Państwowych po II wojnie światowej, w: Od powietrza, głodu, ognia i wojny..., s. 234.

10 AAN, KC PZPR, sygn. XII-4260, Informacja o sytuacji w dniu 3 I 1979 r. godz. 18.00, Warszawa, 3 I 1979, b.pag. W sylwestra do odśnieżania szyn i urządzeń kolejowych zmobilizowano 13,5 tys. osób, a dzień później 18,5 tys.; do akcji wprowadzono sprzęt: 27 pługów, 8 kombajnów i 46 odśnieżarek. Natomiast w nocy z 2 na 3 stycznia na torach pracowało już od 41 do 44 tys. ludzi, 55 pługów, 21 kombajnów i 128 odśnieżarek (za: B. Kruk, op. cit., s. 234-235). 
płomień wychodzący z dysz topił śnieg (środek ten stosowano już zresztą wcześniej, w latach sześćdziesiątych dla udrażniania trasy kolejowej Kraków - Zakopane) ${ }^{11}$.

Tymczasem najważniejszy był załadunek i rozładunek wagonów z węglem dla elektrowni i ciepłowni komunalnych w miastach. Począwszy od 3 stycznia coraz płynniej, choć nie bez przeszkód, realizowano transporty ze śląskich kopalń. Sporym problemem były natomiast awarie wagonów i lokomotyw, zwłaszcza elektrycznych, do spalinowych zaś brakowało paliwa. Ograniczenia w dalekobieżnym ruchu pasażerskim w całym kraju jeszcze 2 stycznia sięgały aż 70\%, dzień później - 65\%. W przypadku kolejowych połączeń lokalnych i podmiejskich wielkości te wynosiły odpowiednio 30 i 20\%, choć w niektórych województwach były o wiele wyższe ${ }^{12}$.

Na początku stycznia rejonowe dyrekcje PKP w Gorzowie Wlkp. i Zielonej Górze miały poważne trudności z utrzymaniem ruchu. Zwrotnice musiały być ogrzewane palnikami benzynowymi i piecykami (żołnierze stosowali nawet miotacze ognia!). 31 grudnia odwołano kilkadziesiąt pociągów lokalnych, a składy dalekobieżne zanotowały opóźnienia sięgające nawet 12 godzin, jak w przypadku pociągu „Ślązak” relacji Zielona Góra - Kraków. 1 stycznia, jedynie w Zielonogórskiem, nie odjechały trzy pociągi dalekobieżne, dwadzieścia towarowych oraz osiem lokalnych ${ }^{13}$. W kolejnych dniach na głównych węzłach kolejowych obu lubuskich województw zdołano zachować przejezdność, co zawdzięczano zmobilizowaniu do odśnieżania pracowników kolei, żołnierzy (także z jednostek sowieckich), członków Związku Socjalistycznej Młodzieży Polskiej oraz ludności z poszczególnych miejscowości - w sumie w Zielonogórskiem pracowało 6,6 tys. osób (w tym 3 tys. wojskowych), w Gorzowskiem zaś tylko 31 grudnia do walki z żywiołem na torach stanęło 800 kolejarzy i kilka tysięcy żołnierzy (problemem nie był jednakże brak ludzi, ale odpowiedniego sprzętu). Ruch pasażerski znacznie ograniczono także dlatego, że priorytet uzyskały dostawy węgla. Dopiero od 9 stycznia przewozy pasażerskie i towarowe wróciły do normy - w przypadku tych ostatnich załadunki i wyładunki przekroczyły nawet średni dobowy poziom z grudnia

11 J. Rolicki, Edward Gierek. Przerwana dekada. Wywiad rzeka, Warszawa 1990, s. 150.

12 AAN, KC PZPR, sygn. XII-4260, Informacja o sytuacji w dniu 3 I 1979 r. godz. 18.00, Warszawa, 3 I 1979, b.pag.

13 AAN, KC PZPR, sygn. XII-3814, Informacja nr III/1/79, Warszawa, 1 I 1979 r. Skutki mrozów i opadów śniegu w Polsce, b.pag. W pierwszych dniach ataku zimy dużym problemem na trasach kolejowych były pękające od mrozu szyny. Na przykład w całym województwie zielonogórskim zanotowano 84 takie przypadki (w tym aż 48 na tzw. Odrzańskiej Magistrali Kolejowej, czyli linii 237 Wrocław - Szczecin). Do naprawy uszkodzonych torów skierowano wówczas 16 spawaczy z zakładów przemysłowych, przede wszystkim z Lubuskiej Fabryki Zgrzeblarek Bawełnianych „Falubaz” oraz Lubuskiego Przedsiębiorstwa Budownictwa Przemysłowego z Nowej Soli (APZG, KW PZPR, sygn. 243, Protokół nr 1 wspólnego posiedzenia Egzekutywy Komitetu Wojewódzkiego PZPR i Prezydium WRN w Zielonej Górze z dnia 12 I 1979, k. 9). 
1978 r. ${ }^{14}$ Gdy w połowie lutego zima znów o sobie przypomniała, w Gorzowskiem udało się utrzymać tylko dwa połączenia dalekobieżne, wszystkie zaś linie lokalne zostały zamknięte (14-15 lutego); z dwóch pociągów osobowych, które utknęły wówczas w zaspach, trzeba było nawet ewakuować pasażerów. 15 i 16 lutego dzień i noc trwało odśnieżanie zwrotnic, rozjazdów i górek rozrządowych m.in. w Gorzowie Wlkp., Rzepinie, Kostrzynie, Zbąszyniu, Żaganiu i Zielonej Górze ${ }^{15}$.

Sytuacja na drogach była równie zła jak na szlakach kolejowych. Na zasypane śniegiem trasy nie zawsze mogły wyjeżdżać pługi z uwagi na zamarzające paliwo. Regionalna i miejska komunikacja autobusowa najcięższe chwile przeżywała od 31 grudnia do 2 stycznia, choć w różnych częściach kraju panowały odmienne warunki. 3 stycznia największe utrudnienia występowały w województwach północnych, nieco lepiej było w województwach środkowych i na Dolnym Śląsku, a całkiem dobry stan dróg był udziałem województw południowych - katowickiego, krakowskiego, opolskiego, bielskiego, tarnowskiego i rzeszowskiego. Przykładowo regularne połączenia autobusowe były realizowane w województwach białostockim i koszalińskim w 40\%, w gdańskim w $38 \%$, w województwie bydgoskim zaś jedynie w 33\%. Niejako na drugim biegunie kształtowała się sytuacja w województwie poznańskim, gdzie 3 stycznia zrealizowano 83\% kursów PKS. Jeszcze o godz. 6 rano 3 stycznia w całym kraju grzęzło w zaspach 410 autobusów ${ }^{16}$. Dopiero 6 stycznia poszczególne komitety wojewódzkie PZPR poinformowały, że „w wyniku dotychczasowych działań osiągnięto istotny postęp w usuwaniu skutków zimy", dzięki czemu sytuacja drogowa i komunikacyjna w większości województw była względnie korzystna (choć nie wszędzie w takim samym stopniu $)^{17}$. Natomiast 8 stycznia w poniedziałek w całym kraju warunki poprawily się na tyle, że na drogi wyruszyło $80-90 \%$ taboru komunikacji miejskiej, przewidzianego rozkładami jazdy ${ }^{18}$.

14 APZG, KW PZPR, sygn. 243, Protokół nr 1 wspólnego posiedzenia Egzekutywy Komitetu Wojewódzkiego PZPR i Prezydium WRN w Zielonej Górze z dnia 12 I 1979, k. 8-9. Całość komunikacji pasażerskiej na trasach dalekobieżnych w Zielonogórskiem przywrócono 11 stycznia (ibidem, k. 11); AAN, KC PZPR, sygn. XII-4263, Syntetyczna informacja o sytuacji w poszczególnych województwach z dnia 7/8 I 1979, b.pag.; Na Ziemi Lubuskiej zima w ofensywie, „Gazeta Lubuska” 2 I 1979, nr 1.

15 APG, KW PZPR, sygn. 395, Teleks nr 37. KW Gorzów do Komitetu Centralnego PZPR, Gorzów, 15 II 1979, k. 38; ibidem, Teleks nr 41. KW Gorzów do Komitetu Centralnego PZPR, Gorzów, 16 II 1979, k. 42; Trudna sytuacja na zachodzie Polski, „Gazeta Lubuska” 16 II 1979, nr 36.

16 AAN, KC PZPR, sygn. XII-4260, Informacja o sytuacji w dniu 3 I 1979 r. godz. 18.00, Warszawa, 3 I 1979, b.pag.

17 AAN, KC PZPR, sygn. XII-3814, Informacja nr III/18/79, Warszawa, 6 I 1979, Usuwanie skutków mrozów i opadów śniegu. Informacje KW, b.pag.

18 AAN, KC PZPR, sygn. XII-3814, Informacja nr III/21/79, Warszawa, 8 I 1979, Usuwanie skutków mrozów i opadów śniegu. Aktualna sytuacja w kraju, b.pag.; ibidem, sygn. XII-4263, Reasumpcja i wnioski wynikające $\mathrm{z}$ oceny sytuacji $\mathrm{w}$ gospodarce komunalnej $\mathrm{w}$ wyniku ataku zimy według stanu z 7 stycznia i nocy z 7 na 8 stycznia br., b.pag. 
W obu województwach Ziemi Lubuskiej na początku stycznia w zaspach utknęly setki różnych pojazdów, przede wszystkim samochodów osobowych. Zawieszono wiele kursów autobusów PKS, a na licznych liniach wystąpiły znaczne opóźnienia. W Gorzowskiem na trasach międzynarodowych udało się utrzymać drożność, jednak gorzej było z arteriami dalszej kolejności odśnieżania - 31 grudnia i 1 stycznia odnotowano 156 nieprzejezdnych odcinków dróg o łącznej długości ok. 900 km ${ }^{19}$. Zaspy wyeliminowały z ruchu połączenia drogowe Barlinek - Pełczyce, Drezdenko - Międzychód, Gorzów Wlkp. - Santok oraz Stare Kurowo - Drezdenko. Do akcji odśnieżania służba drogowa skierowała cały posiadany sprzęt i ludzi, jednak średnie i lekkie pługi nie poradziły sobie z zaspami (sporo do życzenia pozostawiał także ich stan techniczny). Z pomocą przyszło wojsko i ciężkie maszyny, którymi dysponowały Przedsiębiorstwo Transportowo-Sprzętowe Budownictwa „Transbud” oraz Gorzowskie Przedsiębiorstwo Budownictwa Przemysłowego ${ }^{20}$.

W Zielonogórskiem 2 stycznia nie wyjechało na trasy 50\% autobusów PKS, zwłaszcza dalekobieżnych. W kolejnych dniach sytuacja zaczęła wracać stopniowo do normy, zarówno w odniesieniu do komunikacji pasażerskiej, jak również środków transportu obsługujących handel wewnętrzny. Była to głównie zasługa pracy służb drogowych, dzięki czemu arterie I i II kolejności odśnieżania udrożniono od 2 stycznia (szlaki III kolejności odśnieżania, ok. 2 tys. km, były nieprzejezdne nawet do 5 stycznia). Początkowo każdej doby śnieg z dróg usuwało 400 osób, a od 3 stycznia - 550. W ich dyspozycji znajdowało się 112 sztuk sprzętu odśnieżającego oraz 100 jednostek do zwalczania skutków gołoledzi. Od 4 stycznia na szlakach drogowych pojawili się także żołnierze wykorzystujący 10 ciężkich pługów (spycharek gąsienicowych BAT-M). Najgorsza sytuacja panowała w samej Zielonej Górze, gdzie nie przygotowano żadnego sprzętu ${ }^{21}$.

Od 12 lutego, wraz z nawrotem mrozów i opadów śniegu, sytuacja na lubuskich szlakach do pewnego stopnia się powtórzyła. W połowie miesiąca w Gorzowskiem z powodu zasp ruch kołowy wstrzymano m.in. na trasach Choszczno - Barlinek, Drezdenko - Międzychód oraz Bolemin - Lubniewice. Do zakładów i przedsiębiorstw jedynie 17 lutego nie dowieziono tutaj 2 tys. pracowników. W Zielonogórskiem nieprzejezdne były w tym czasie drogi w okolicach Świebodzina

${ }^{19}$ Na Ziemi Lubuskiej zima w ofensywie, „Gazeta Lubuska” 2 I 1979, nr 1. 2 stycznia gorzowski Komitet Wojewódzki PZPR w informacji dla KC podawał, że nieprzejezdnych było ok. $400 \mathrm{~km}$ dróg lokalnych na północy województwa, a także 17-kilometrowy odcinek drogi II kolejności odśnieżania, który po odśnieżeniu został ponownie zasypany (APG, KW PZPR, sygn. 395, Teleks nr 2. KW Gorzów do Komitetu Centralnego PZPR, Gorzów, 2 I 1979, k. 2).

${ }^{20}$ Na Ziemi Lubuskiej zima w ofensywie, „Gazeta Lubuska” 2 I 1979, nr 1.

21 APZG, KW PZPR, sygn. 243, Protokół nr 1 wspólnego posiedzenia Egzekutywy Komitetu Wojewódzkiego PZPR i Prezydium WRN w Zielonej Górze z dnia 12 I 1979, k. 9. Co ciekawe, oficjalnie w „Gazecie Lubuskiej” podawano, że w Zielonogórskiem 2 stycznia nieprzejezdnych było tylko 570 km dróg III kolejności odśnieżania (Ziemia Lubuska w okowach zimy, „Gazeta Lubuska” 3 I 1979, nr 2). 
i Wolsztyna (łącznie ok. 150 km) i odwołano 57 kursów PKS. Do akcji odśnieżania zaangażowano ponownie, oprócz służb drogowych, wojsko, załogi przedsiębiorstw i ludność poszczególnych miejscowości. 16 lutego na drogach obu lubuskich województw, nie licząc żołnierzy i sprzętu wojskowego, pracowało 105 różnych pługów odśnieżających, 65 równiarek i spychaczy oraz 95 piaskarek, obsługiwanych przez ok. 600 ludzi. W kolejnych dniach szczególnie ciężka sytuacja panowała na szlakach województwa gorzowskiego. Na odcinku międzynarodowej drogi E-14 między Gorzowem Wlkp. a Lipianami 17 lutego w gigantycznym korku utknęło ponad tysiąc pojazdów. Następnego dnia w samym Gorzowie Wlkp., na apel Komitetu Miejskiego PZPR, do usuwania śniegu z głównych ciągów komunikacyjnych przystąpiło 12 tys. osób, mimo że była to niedziela ${ }^{22}$.

Obok zaśnieżonych dróg bolączką transportu i komunikacji samochodowej były problemy techniczne wywołane mrozem. Na przykład wiele autobusów miejskich w Warszawie stało w zajezdniach $\mathrm{z}$ włączonymi silnikami przez całe noce, aby możliwe było ich uruchomienie z samego rana. Jeśli natomiast silnik zgasł, to kierowcy i mechanicy... rozpalali pod nim ogień, żeby rozgrzać olej. Podobne kłopoty były $\mathrm{z}$ hamulcami pneumatycznymi, wyposażonymi w filtry powietrza, zatrzymującymi wodę, która często zamarzała ${ }^{23}$. Również z województw zielonogórskiego i gorzowskiego informowano, że w niektórych autobusach przy temperaturze poniżej $-12^{\circ} \mathrm{C}$ z oleju napędowego zaczynała wydzielać się parafina, co doprowadzało do zatykania się przewodów. Dlatego też wystąpiła konieczność dostaw paliwa bardziej odpornego na mrozy ${ }^{24}$. W Gorzowskiem 2 i 3 stycznia transport publiczny ratowały jednostki Śląskiego Okręgu Wojskowego, dostarczając 10 tys. litrów oleju napędowego o niższej temperaturze zamarzania ${ }^{25}$. Trudno było sobie jednak poradzić ze szwankującymi autobusami Jelcz PR110, produkowanymi na licencji francuskiego Berlieta, których przewody, wykonane z tworzyw sztucznych, nagminnie pękały przy silnych mrozach. Dochodziły do tego zamykane pneumatycznie drzwi z zamarzającymi mechanizmami oraz mało odporne na ujemne temperatury akumulatory ${ }^{26}$.

22 APG, KW PZPR, sygn. 395, Teleks nr 36. KW Gorzów do Komitetu Centralnego PZPR, Gorzów, 14 II 1979, k. 37; ibidem, Teleks nr 37. KW Gorzów do Komitetu Centralnego PZPR, Gorzów, 15 II 1979, k. 38; ibidem, Teleks nr 44. KW Gorzów do Komitetu Centralnego PZPR, Gorzów, 19 II 1979, k. 45; Zima nie kapituluje, „Gazeta Lubuska” 15 II 1979, nr 35; Trudna sytuacja na zachodzie Polski, „Gazeta Lubuska” 16 II 1979, nr 36; Na zachodzie Polski główne drogi przejezdne, „Gazeta Lubuska” 17 II 1979, nr 37; Trudna sytuacja na drogach i kolejach zachodniej Polski, „Gazeta Lubuska” 19 II 1979, nr 38.

${ }^{23}$ G. Sieczkowski, op. cit., s. 14.

24 AAN, KC PZPR, sygn. XII-4262, Ocena sytuacji w gospodarce komunalnej powstałej w wyniku ataku zimy oraz o środkach zaradczych (stan na 4/5 I 1979), b.pag.

25 Ibidem; APG, KW PZPR, sygn. 395, Teleks nr 2. KW Gorzów do Komitetu Centralnego PZPR, Gorzów, 2 I 1979, k. 2; Ziemia Lubuska w okowach zimy, „Gazeta Lubuska” 3 I 1979, nr 2

26 AAN, KC PZPR, sygn. XII-4262, Ocena sytuacji w gospodarce komunalnej powstałej w wyniku ataku zimy oraz o środkach zaradczych (stan na 4/5 I 1979), b.pag.; G. Sieczkowski, op. cit., s. 68-69. 


\section{Energetyka i ciepłownictwo}

Szczególnie groźne i uciążliwe na początku zimy stulecia były uszkodzenia i niesprawności krajowego sytemu energetycznego, rzutujące na wszystkie obszary gospodarki i życia społecznego. 2 stycznia w godzinach wieczornych pracujące z wielkimi kłopotami elektrownie dostarczyły w skali całej Polski 13200 MW, dzień później zaś zdołały osiągnąć poziom 14300 MW. Odbiorcy w dalszym ciągu nie otrzymywali 1900 MW, przy czym aż 300 MW niedoboru dotyczyło gospodarstw domowych. Nieusunięte jeszcze uszkodzenia w elektrowniach uniemożliwiały wytworzenie kolejnych $3000 \mathrm{MW}^{27}$.

W Gorzowskiem i Zielonogórskiem, tak jak i w innych częściach kraju, najbardziej odczuwalne były wyłączenia prądu, spowodowane awariami głównych dostawców energii elektrycznej dla obu województw: Elektrowni Dolna Odra, Elektrowni Turów oraz Zespołu Elektrowni Pątnów-Adamów-Konin. W normalnych warunkach energetyczne zapotrzebowanie województwa zielonogórskiego wahało się od 190 do 215 MW. Natomiast w dniach między 31 grudnia a 2 stycznia 1979 r. dotarło tutaj zaledwie 60-70 MW, 3 stycznia zaś - 140 MW. Wymusiło to wyłączanie z sieci zaopatrzenia w prąd nie tylko poszczególnych miast i wsi, ale całych rejonów energetycznych (np. Sulechowa, Wolsztyna i Szprotawy z 31 grudnia na 1 stycznia), co z kolei wywołało liczne awarie w ciepłowniach i urządzeniach grzewczych $^{28}$. Podobna sytuacja wystąpiła w województwie gorzowskim, gdzie w tym samym czasie przerwy w dostawach energii odczuły Słubice, Kostrzyn, Sulęcin, Choszczno, Międzyrzecz i Strzelce Krajeńskie. Liczni energetycy z tego terenu spędzili noc sylwestrową naprawiając uszkodzone przez wichurę linie napowietrzne, do których niejednokrotnie mieli utrudniony dostęp, zwłaszcza na polach i terenach zalesionych. Później w wielu miejscach na druty elektryczne przewracały się także oblodzone drzewa. W samym Gorzowie Wlkp. awariom ulegały sieci niskiego napięcia, co najdotkliwiej odczuwali indywidualni odbiorcy ${ }^{29}$.

Jednym z najmniej wydolnych w okresie zimy stulecia okazał się system ciepłowniczy, zarówno w zakresie organizacji funkcjonowania, jak również jego

27 AAN, KC PZPR, sygn. XII-4260, Informacja o sytuacji w dniu 3 I 1979 r. godz. 18.00, Warszawa, 3 I 1979, b.pag.

28 APZG, KW PZPR, sygn. 243, Protokół nr 1 wspólnego posiedzenia Egzekutywy Komitetu Wojewódzkiego PZPR i Prezydium WRN w Zielonej Górze z dnia 12 I 1979, k. 4-5; AAN, KC PZPR, sygn. XII-3814, Informacja nr III/1/79, Warszawa, 1 I 1979, Skutki mrozów i opadów śniegu w Polsce, b.pag. Oprócz awaryjnych lub planowanych przerw w dostawach energii władze wojewódzkie z Zielonej Góry podjęły decyzję o znacznym ograniczeniu nocnego oświetlenia ulic w miastach (APZG, KW PZPR, sygn. 243, Informacja o sytuacji społeczno-gospodarczej w województwie zielonogórskim wynikłej z ostrego ataku zimy w dniach od 30 XII 1978 r. do dnia 9 I 1979 r., k. 78).

${ }^{29}$ Na Ziemi Lubuskiej zima w ofensywie, „Gazeta Lubuska” 2 I 1979, nr 1; Ziemia Lubuska w okowach zimy, „Gazeta Lubuska” 3 I 1979, nr 2. 
bazy technicznej. W obowiązujących do roku 1978 zasadach gromadzenia opału przewidywano, że przed okresem grzewczym każda z ok. 7 tys. kotłowni i elektrociepłowni w całym kraju powinna dysponować $70 \%$ zapasów opału, niezbędnych $\mathrm{w}$ danym sezonie. Tymczasem w 1978 r. podjęto decyzję o zmniejszeniu wielkości tychże rezerw dla kotłowni komunalnych i na sezon grzewczy 1978/1979 zgromadzono jedynie $45 \%$ potrzebnego paliwa. W efekcie już na początku stycznia w niektórych rejonach zaczęło brakować węgla. W skali Polski szacowano (stan na 8 stycznia), że zapasy węgla i miału węglowego, którymi dysponują elektrociepłownie i kotłownie komunalne, wystarczą jedynie na siedem $\mathrm{dni}^{30}$.

Niskich temperatur i obfitych opadów śniegu nie wytrzymały ciepłownie i lokalne systemy grzewcze. Tylko do 3 stycznia odnotowano w kraju 40 groźnych awarii w kotłowniach oraz sieciach przemysłowych doprowadzających ciepło do osiedli mieszkaniowych. Większość uszkodzeń została wywołana przerwami w dostawach energii elektrycznej. W całym kraju 3 stycznia niedogrzanych było 550 tys. mieszkań, z czego aż 250 tys. w Warszawie i województwie stołecznym. Analogiczne problemy wystąpiły też m.in. w Świnoujściu, Gdańsku, Wałbrzychu, Częstochowie czy Ciechanowie. Dopiero w kolejnych dniach (6-7 stycznia) sytuacja zaczęła ulegać stopniowemu polepszeniu, zachowywano ciągłość pracy kotłowni komunalnych i sprawniej usuwano awarie, czemu w znacznej mierze przysłużyła się poprawa pogody. Natomiast w celu uniknięcia skutków przerywania dostaw energii w miejskich ciepłowniach proponowano, aby największe jednostki tego typu wyposażać w agregaty prądotwórcze dużej mocy ${ }^{31}$.

W Zielonogórskiem rezerwy opału w ciepłowniach miały wystarczyć (stan z 8 stycznia) jedynie na dwa do pięciu dni, zapasy koksu zaś najwyżej na dwatrzy dni. Jedynie elektrociepłownia w Zielonej Górze była w nieco lepszej sytuacji, dysponując 10 stycznia dziesięciodniową rezerwą opału - ok. 7,5 tys. $\operatorname{ton}^{32} .8$ stycznia władze partyjne i administracyjne województwa szacowały, że do 15 stycznia łączne minimalne zapotrzebowanie wyniesie 35 tys. ton węgla kamiennego oraz 3 tys. ton koksu, $\mathrm{z}$ tego na potrzeby ludności -9 tys. ton, dla

30 AAN, KC PZPR, sygn. XII-4262, Ocena sytuacji w gospodarce komunalnej powstałej w wyniku ataku zimy oraz o środkach zaradczych (stan na 4/5 I 1979), b.pag.; ibidem, sygn. XII-4263, Reasumpcja i wnioski wynikające $\mathrm{z}$ oceny sytuacji w gospodarce komunalnej w wyniku ataku zimy według stanu z 7 stycznia i nocy z 7 na 8 stycznia br., b.pag.

31 AAN, KC PZPR, sygn. XII-4260, Informacja o sytuacji w dniu 3 I 1979 r. godz. 18.00, Warszawa, 3 I 1979, b.pag.; ibidem, sygn. XII-4262, Ocena sytuacji w gospodarce komunalnej powstałej w wyniku ataku zimy oraz o środkach zaradczych (stan na 4/5 I 1979), b.pag.; ibidem, sygn. XII-3814, Informacja nr III/21/79, Warszawa, 8 I 1979, Usuwanie skutków mrozów i opadów śniegu. Aktualna sytuacja w kraju, b.pag.

32 AAN, KC PZPR, sygn. XII-4263, Reasumpcja i wnioski wynikające z oceny sytuacji w gospodarce komunalnej w wyniku ataku zimy według stanu z 7 stycznia i nocy z 7 na 8 stycznia br., b.pag.; APZG, KW PZPR, sygn. 243, Protokół nr 1 wspólnego posiedzenia Egzekutywy Komitetu Wojewódzkiego PZPR i Prezydium WRN w Zielonej Górze z dnia 12 I 1979, k. 5-6. 
gospodarki komunalnej - 9 tys. ton, dla przemysłu - 15 tys. ton oraz dla rolnictwa uspołecznionego - 2 tys. ton. Wobec utrudnień w dostawach węgla brunatnego z Turoszowa potrzeby w zakresie tego paliwa obliczono na minimum 4 tys. ton ${ }^{33}$. Skromne zapasy opału w zielonogórskich kotłowniach uzupełniano awaryjnie, dokonując przerzutów węgla z zakładów pracy, a także kierując do województwa dwa transporty miału węglowego (ok. 5 tys. ton), przeznaczonego wcześniej dla Elektrowni Dolna Odra ${ }^{34}$.

Równie dramatyczna sytuacja pod względem zaopatrzenia w węgiel dla gospodarki komunalnej panowała w drugim lubuskim województwie. Gorzowski KW PZPR informował 5 stycznia, że od początku roku do regionu nie dotarły na cele komunalne żadne dostawy opału. W szczególnie trudnym położeniu pod tym względem znajdowały się jednostki służby zdrowia, zwłaszcza niedogrzane szpitale. W Kostrzynie i Choszcznie już 2 stycznia węgiel dla kotłowni osiedlowych był na wyczerpaniu. W gorzowskiej elektrociepłowni szacowano z kolei 2 stycznia, że rezerwy opału skończą się po pięciu-sześciu dniach. Pierwszy pociąg wahadłowy z węglem ze Śląska pojawił się dopiero 6 stycznia $^{35}$.

Oczywiście najistotniejsze ze społecznego punktu widzenia było zabezpieczenie ciepła w mieszkaniach. Ciężka sytuacja panowała zwłaszcza w nowych osiedlach budowanych z wielkiej płyty, które okazały się nieprzygotowane na tak mroźną zimę. W nieocieplonych domach z betonu, posiadających na dodatek sporo przeszklonych ścian zewnętrznych (głównie klatek schodowych), temperatura spadała do kilku stopni Celsjusza, jak choćby na warszawskim Ursynowie czy w Gdańsku ${ }^{36}$. Najwięcej awarii dotyczyło pękania przewodów i grzejników na korytarzach, szczególnie w pobliżu drzwi wejściowych - do 3 stycznia w całym kraju jedynie w lokalach mieszkalnych popękało 30 tys. kaloryferów (!) ${ }^{37}$.

33 AAN, KC PZPR, sygn. XII-4263, Informacja o aktualnej sytuacji w województwie zielonogórskim w dniu 8 I 1979, b.pag.

34 APZG, KW PZPR, sygn. 243, Informacja o sytuacji społeczno-gospodarczej w województwie zielonogórskim wynikłej z ostrego ataku zimy w dniach od 30 XII 1978 r. do dnia 9 I 1979 r., k. 76.

35 AAN, KC PZPR, sygn. XII-3814, Informacja nr III/4/79, Warszawa, 2 I 1979, Usuwanie skutków mrozów i opadów śniegu, b.pag.; ibidem, Informacja nr III/18/79, Warszawa, 6 I 1979, Usuwanie skutków mrozów i opadów śniegu. Informacje KW, b.pag.; APG, KW PZPR, sygn. 395, Teleks nr 2. KW Gorzów do Komitetu Centralnego PZPR, Gorzów, 2 I 1979, k. 2; ibidem, Teleks nr 7. KW Gorzów do Komitetu Centralnego PZPR, 5 I 1979, k. 8; ibidem, Teleks nr 10. KW Gorzów do Komitetu Centralnego PZPR, 7 I 1979, k. 11.

36 Zimowe doświadczenia spowodowały, że władze państwowe już na początku stycznia 1979 r. zaczęły poważnie zastanawiać się nad wprowadzeniem zmian w dokumentacji technicznej przyszłych bloków mieszkalnych w celu polepszenia ich izolacji oraz zmniejszenia stopnia przeszklenia ścian (AAN, KC PZPR, sygn. XII-4262, Ocena sytuacji w gospodarce komunalnej powstałej w wyniku ataku zimy oraz o środkach zaradczych [stan na 4/5 I 1979], b.pag.).

37 M.F. Rakowski, Dzienniki polityczne 1979-1981, t. 7, Warszawa 2004, s. 11. Zdarzało się, że woda z pękniętych kaloryferów w zamkniętych mieszkaniach zalewała lokale na niższych piętrach. W takich wypadkach interweniować musiała milicja i Straż Pożarna (M. Wesołowska, op. cit., s. 3). 
Uszkodzenia te były wynikiem przerw w dopływie gorącej wody do grzejników wskutek obniżenia temperatury wyjściowej w elektrociepłowniach oraz wielogodzinnych przerw w dostawach prądu do kotłowni. Powodowało to natychmiastowe unieruchomienie pomp tłoczących ciepłą wodę do mieszkań - tylko do 5 stycznia w skali Polski stwierdzono ok. 15 tys. takich awarii. We wszystkich województwach powołano specjalne ekipy do usuwania i wymiany uszkodzonych grzejników - liczba zaangażowanych do pracy monterów wyniosła ok. 6 tys. osób. Wkrótce zabrakło zapasowych kaloryferów i trzeba było naprawiać te, które dało się zreperować - szacowano, że tą drogą odzyska się ich ok. 30\% (zdarzało się, że grzejniki zabezpieczano nawet tekturą i papierem!). Władze partyjne już 3 stycznia zdecydowały o zwiększeniu produkcji kaloryferów, jednak deficyt dotyczył również rur wodociągowych i centralnego ogrzewania oraz gazów technicznych. Jeszcze gorzej niż w budynkach mieszkalnych przedstawiała się likwidacja awarii w obiektach użyteczności publicznej, szkołach, sklepach, magazynach oraz zakładach przemysłowych ${ }^{38}$.

Problemy z funkcjonowaniem kotłowni komunalnych odnotowano praktycznie we wszystkich lubuskich miastach. Awarie wywołały przerwy w dostawach ciepła w trzech dużych osiedlach w Zielonej Górze oraz pojedynczych osiedlach w Świebodzinie, Nowej Soli, Sulechowie, Żarach i Nowogrodzie Bobrzańskim ${ }^{39}$. W Gorzowie Wlkp. 1 stycznia doszło do awarii w ciepłowni, zapewniającej ogrzewanie 14-tysięcznemu Osiedlu Staszica. Wprawdzie oficjalnie na łamach „Gazety Lubuskiej” mówiono jedynie o „pewnych trudnościach”, to w rzeczywistości uszkodzenia były poważne i udało się je usunąć dopiero 3 stycznia przed południem. Przyczyna awarii w ciepłowni wynikała z przerwania dostaw prądu, co spowodowało wyłączenie kotłów; kiedy skończyły się kłopoty z energią, w instalacji ciepłowniczej zabrakło z kolei wody, a później doszły do tego pęknięcia kaloryferów i rur. Do napraw uszkodzeń zmobilizowano pracowników Wojewódzkiego Przedsiębiorstwa Energetyki Cieplnej (wyposażonych przez wojsko w sprzęt radiotelefoniczny), a także członków załóg niektórych gorzowskich przedsiębiorstw. Dzięki temu 3 stycznia przed południem do kaloryferów większości budynków na Osiedlu Staszica popłynęła gorąca woda, ale 500 mieszkań musiało czekać na

38 AAN, KC PZPR, sygn. XII-4262, Ocena sytuacji w gospodarce komunalnej powstałej w wyniku ataku zimy oraz o środkach zaradczych (stan na 4/5 I 1979), b.pag.; ibidem, sygn. XII-4263, Reasumpcja i wnioski wynikające $\mathrm{z}$ oceny sytuacji w gospodarce komunalnej $\mathrm{w}$ wyniku ataku zimy według stanu z 7 stycznia i nocy z 7 na 8 stycznia br., b.pag.; J. Kowalski, Zima stulecia, Portal „Rzeczypospolitej”, 21 I 2008, https://www.rp.pl/artykul/85895-Zima-stulecia.html (dostęp: 5 VII 2020).

39 APZG, KW PZPR, sygn. 243, Protokół nr 1 wspólnego posiedzenia Egzekutywy Komitetu Wojewódzkiego PZPR i Prezydium WRN w Zielonej Górze z dnia 12 I 1979, k. 6; ibidem, Informacja o sytuacji społeczno-gospodarczej w województwie zielonogórskim wynikłej z ostrego ataku zimy w dniach od 30 XII 1978 r. do dnia 9 I 1979 r., k. 76; Ziemia Lubuska w okowach zimy, „Gazeta Lubuska” 3 I 1979, nr 2. 
ciepło jeszcze kilka godzin dłużej ${ }^{40}$. W różnych miejscowościach obu lubuskich województw tylko do 4 stycznia odnotowano awarie rur ciepłowniczych i grzejników w ponad stu klatkach schodowych i wymieniono kilkaset kaloryferów. Do usuwających awarie ekip pracowników ciepłowni zarówno w Gorzowskiem, jak i Zielonogórskiem dołączono znaczną liczbę fachowców z unieruchomionych zakładów pracy ${ }^{41}$.

W kontekście kłopotów ciepłownictwa warto dokładniej przyjrzeć się sytuacji elektrociepłowni w Zielonej Górze, ponieważ w podobnych warunkach działały wówczas inne jednostki tego typu. Elektrociepłownia, której rozruch nastąpił w 1974 r., od początku stycznia funkcjonowała - co trzeba uznać za sukces - bez większych kłopotów, nie licząc trudności z dotarciem do pracy niektórych osób, zaskoczonych atakiem zimy poza miastem (głównie podczas wyjazdów i imprez sylwestrowych). Najpierw niemal cała załoga uczestniczyła w odśnieżaniu terenu przedsiębiorstwa, a następnie wielu jej członków nie schodziło ze swoich stanowisk przez 24 godziny na dobę i to przez dwa-trzy dni z rzędu. Kiedy po jakimś czasie do elektrociepłowni zaczęły docierać transporty węgla, ich opróżnianie stanowiło prawdziwe wyzwanie - „trzeba było kucia, aby rozładować wagony, do czego sprowadzano także żołnierzy - wspominali pracownicy, - węgiel zrzucano prosto na tory, był on zamarznięty $\mathrm{w}$ wielkich bryłach, $\mathrm{z}$ których rozkuwaniem nie nadążano"42. Zdaniem kierownictwa przedsiębiorstwa przymarzaniu węgla do ścian wagonów winni byli w znacznej mierze dostawcy, czyli kopalnie, które w trakcie załadunku nie stosowały specjalnych, zapobiegających takim sytuacjom środków chemicznych. Później, przy niskich temperaturach, węgiel trudno było oddzielić od burt wagonów nie tylko przy pomocy kilofa, ale nawet młota pneumatycznego ${ }^{43}$.

40 APG, KW PZPR, sygn. 395, Teleks nr 1. KW Gorzów do Komitetu Centralnego PZPR, 2 I 1979, k. 1; ibidem, Teleks nr 2. KW Gorzów do Komitetu Centralnego PZPR, Gorzów, 2 I 1979, k. 2; Na Ziemi Lubuskiej zima w ofensywie, „Gazeta Lubuska” 2 I 1979, nr 1.

41 AAN, KC PZPR, sygn. XII-4262, Informacja o sytuacji w gospodarce komunalnej w poszczególnych województwach - według stanu na 4/5 I 1979 r., b.pag.; ibidem, Informacja na temat sytuacji $\mathrm{w}$ gospodarce komunalnej oraz podejmowanych środkach zaradczych $\mathrm{w}$ niektórych województwach w nocy z 3 na 4 I 1979 r., b.pag.; Ziemia Lubuska w okowach zimy, „Gazeta Lubuska” 3 I 1979, nr 2. W Zielonogórskiem uruchomiono produkcję dodatkowych grzejników w Dolnośląskich Zakładach Odlewniczych w Szprotawie, gdzie do 10 stycznia zdołano wytworzyć 500 metrów bieżących kaloryferów, kolejne zaś $1500 \mathrm{~m}$ uzyskano w tym czasie z dostaw centralnych (APZG, KW PZPR, sygn. 243, Protokół nr 1 wspólnego posiedzenia Egzekutywy Komitetu Wojewódzkiego PZPR i Prezydium WRN w Zielonej Górze z dnia 12 I 1979, k. 7; Skuteczność i ofiarność - czynniki decydujące w zmaganiach z ofensywą zimy na Ziemi Lubuskiej, „Gazeta Lubuska” 4 I 1979, nr 3).

${ }^{42}$ Relacje pracowników Elektrociepłowni „Zielona Góra” S.A. z lutego 2010 r.: Mariana Babiucha, Ryszarda Radzia, Ryszarda Piotrowskiego, Włodzimierza Rojka i Romana Pidłypczaka (w zbiorach autora).

${ }^{43}$ Ibidem. 
Problemom z ogrzewaniem mieszkań towarzyszyły inne trudności gospodarki komunalnej w miastach, jak na przykład kwestia usuwania śmieci z zasypanych śniegiem osiedli mieszkaniowych, na które nie mogły dotrzeć na czas odpowiednie służby. W Zielonej Górze skoncentrowano się przede wszystkim na odbiorze odpadków z wysokich bloków, gdzie gromadziły się one najszybciej. W całym województwie gorzowskim 7 i 8 stycznia wywóz śmieci kształtował się na poziomie $80 \%$ planów dziennych. W wielu miejscach obu województw służby w dalszym ciągu miały utrudniony dostęp do pojemników na odpady. Sytuacja polepszyła się nieco w dniach 6-7 stycznia, wraz poprawą warunków pogodowych ${ }^{44}$.

\section{Handel i zaopatrzenie}

Obok ciepła w mieszkaniach, równie istotne było zapewnienie zaopatrzenia ludności w żywność. Tymczasem w sklepach, których asortyment i tak od dawna się pogarszał, w pierwszych dniach stycznia zaczynało brakować podstawowych artykułów spożywczych. Z placówek szybko znikało pieczywo, wykupywano masowo mąkę, kaszę, konserwy, sól, a także świece i znicze (tych ostatnich zabrakło wkrótce w całym kraju). W niektórych miejscowościach wprowadzono reglamentację produktów żywnościowych oraz benzyny ${ }^{45}$. Wszystkie komitety wojewódzkie partii informowały, że w sklepach utrzymywał się też niedostatek wielu towarów przemysłowych, szczególnie obuwia zimowego męskiego i damskiego, ciepłej bielizny męskiej i chłopięcej, rajtuz, skarpet wełnianych, tkanin bawełnianych, pościelowych i welwetowych. Niedostateczne zaopatrzenie dotyczyło również zmechanizowanego sprzętu gospodarstwa domowego, produktów kosmetyczno-chemicznych (pasty do butów i podłóg, proszków do prania i szorowania) oraz akumulatorów samochodowych, których cena na czarnym rynku sięgała nawet 2 tys. $z^{46}$.

W obu lubuskich województwach 2 stycznia tabor zgromadzony w Przedsiębiorstwie Transportowym Handlu Wewnętrznego nieomal w komplecie zdołał wyjechać ze swoich baz ok. godz. 3 nad ranem (pewne kłopoty odnotowano tylko w Gubinie). Dzięki temu w Zielonogórskiem ciągłość zaopatrzenia ludności w podstawowe

${ }^{44}$ AAN, KC PZPR, sygn. XII-4262, Informacja o sytuacji w gospodarce komunalnej w poszczególnych województwach - według stanu na 4/5 I 1979 r., b.pag.; ibidem, sygn. XII-4263, Syntetyczna informacja o sytuacji w poszczególnych województwach z dnia 7/8 I 1979, b.pag.; ibidem, sygn. XII-3814, Informacja nr III/21/79, Warszawa, 8 I 1979, Usuwanie skutków mrozów i opadów śniegu. Aktualna sytuacja w kraju, b.pag.

${ }^{45}$ M. Zaremba, Wywrotowa zima..., s. 63. Na przykład w Szczecinie kierowcy prywatnych samochodów mogli jednorazowo zatankować tylko 10 litrów benzyny, taksówkarze zaś 20 litrów. 13 stycznia, bez wcześniejszych zapowiedzi, władze podniosły ceny paliw płynnych (ibidem).

46 AAN, KC PZPR, sygn. XII-3814, Informacja nr III/62/79, Warszawa, 1 II 1979, Zaopatrzenie rynku w podstawowe artykuły żywnościowe i przemysłowe w styczniu br., b.pag.; M. Zaremba, Wywrotowa zima..., s. 63. 
artykuły spożywcze (pieczywo, mleko, mięso), pomimo przerw w dostawach prądu i absencji pracowników, została zachowana zarówno w miejskiej, jak i wiejskiej sieci handlowej. W odróżnieniu od niektórych województw w innych częściach kraju, nie było tutaj konieczności wprowadzania ograniczeń w sprzedaży, jednak przez cały styczeń odczuwano niedobory masła, margaryny, oleju jadalnego, smalcu oraz słoniny. Czasami, szczególnie na początku miesiąca, występowała konieczność „przerzutu” pieczywa, np. z Zielonej Góry do Wolsztyna i Kożuchowa. Większość zakładów piekarniczych ograniczyła też wypiek chleba do jednego gatunku ${ }^{47}$.

Gorsza sytuacja panowała w Gorzowskiem, gdzie z powodu przerw w dostawach energii wiele piekarni znacznie zmniejszyło produkcję; to samo dotyczyło przetworów mlecznych. W tej sytuacji 2 stycznia tutejszy KW PZPR zmuszony był podjąć decyzję o racjonowaniu sprzedaży masła i mąki. W województwie na ogół w pełni pokrywano zaopatrzenie sklepów w podstawowe towary: makarony, cukier, ryż, mleko i dżemy; odnotowywano natomiast braki - i to przez cały styczeń - herbaty wysokogatunkowej, mleka w proszku, kaszy gryczanej, pieprzu i koncentratu pomidorowego. Innym problemem w Gorzowskiem, szczególnie 2 i 3 stycznia, były trudności w dostarczaniu towarów spożywczych do sklepów wiejskich na północy województwa w rejonie Recza i Choszczna. Docierano tam w miarę usuwania zasp i udrażniania dróg. Niejednokrotnie artykuły do sklepów dowożono ciągnikami, a nawet chłopskimi furmankami i saniami. Niedobory pieczywa w takich miastach jak Barlinek i Pełczyce uzupełniano, podobnie jak w przypadku Zielonej Góry, dostawami z samego Gorzowa Wlkp. ${ }^{48} \mathrm{~W}$ następnych kilku dniach rytmiczność zaopatrywania sklepów zmieniała się na lepsze, wraz z poprawą warunków pogodowych. Jednak, począwszy od 10 lutego przez następnych kilka dni, po ponownych obfitych opadach śniegu i zamieciach, północna część województwa gorzowskiego na powrót została nieomal odcięta od świata. W gminach Pełczyce, Recz, Drawno, Myślibórz, Bierzwnik i Korzęcin problemem był dowóz nawet artykułów pierwszej potrzeby, a mleko i chleb do wiejskich sklepów znów musiały dostarczać furmanki i sanie ${ }^{49}$.

${ }^{47}$ APZG, KW PZPR, sygn. 243, Protokół nr 1 wspólnego posiedzenia Egzekutywy Komitetu Wojewódzkiego PZPR i Prezydium WRN w Zielonej Górze z dnia 12 I 1979, k. 10; AAN, KC PZPR, sygn. XII-3814, Informacja nr III/62/79, Warszawa, 1 II 1979, Zaopatrzenie rynku w podstawowe artykuły żywnościowe i przemysłowe w styczniu br., b.pag.; Ziemia Lubuska w okowach zimy, „Gazeta Lubuska” 3 I 1979, nr 2.

48 AAN, KC PZPR, sygn. XII-3814, Informacja nr III/4/79, Warszawa, 2 I 1979, Usuwanie skutków mrozów i opadów śniegu, b.pag.; APG, KW PZPR, sygn. 395, Teleks nr 4. KW Gorzów do Komitetu Centralnego PZPR, Gorzów, 3 I 1979, k. 4; ibidem, Teleks nr 29. KW Gorzów do Komitetu Centralnego PZPR, Informacja dotycząca zaopatrzenia rynku gorzowskiego w podstawowe artykuły spożywcze i przemysłowe w styczniu br., Gorzów, 1 II 1979, k. 30.

49 APG, KW PZPR, sygn. 395, Teleks nr 34. KW Gorzów do Komitetu Centralnego PZPR, Gorzów, 9 II 1979, k. 35; ibidem, Teleks nr 36. KW Gorzów do Komitetu Centralnego PZPR, Gorzów, 14 II 1979, k. 37. 
Zmorą zaopatrzeniowców i handlowców w styczniu był nie tylko brak towarów w sklepach, ale także rozliczne awarie, do których, z powodu mrozu, dochodziło w budynkach sklepowych czy piekarniczych. Przykładowo Wojewódzkie Przedsiębiorstwo Handlu Wewnętrznego (WPHW) w Zielonej Górze już 2 stycznia odnotowało uszkodzenia w 59 placówkach handlowych, usługowych oraz magazynowych, związane z zamarzaniem przewodów grzewczych i wodociągowych, pękaniem pieców i instalacji centralnego ogrzewania oraz przerwami w dostawach prądu. Wiele sklepów nie zostało otwartych, gdyż nie dotarł do nich personel. Od 2 stycznia kilkuset pracowników WPHW, w ramach czynu społecznego, przystąpiło do odśnieżania obiektów magazynowych, handlowych i biurowych; rozpoczęto ocenę strat i usuwanie z magazynów towarów zniszczonych mrozami; codziennie 50 pracowników dozoru technicznego WPHW likwidowało na bieżąco uszkodzenia; w rejonie Lubska, Żar i Żagania zorganizowano ośmioosobową brygadę remontową, która zajęła się usuwaniem awarii $\mathrm{w}$ tamtejszych punktach przedsiębiorstwa (m.in. wymianą uszkodzonych pieców c.o.), uzupełniono - oczywiście w miarę skromnych możliwości - zapasy węgla w różnych placówkach oraz wyznaczono dyżury członków wojewódzkiego kierownictwa WPHW ${ }^{50}$. Również Wojewódzka Spółdzielnia Spożywców „Społem” w Zielonej Górze informowała 9 stycznia o dużych stratach (ok. 4 mln zł) w zarządzanych przez siebie sklepach oraz piekarniach; dotyczyło to uszkodzeń i awarii w poszczególnych obiektach, utraty produkcji piekarniczej i ciastkarskiej, zmniejszonych obrotów w sklepach, zwiększonego zużycia energii i opału, większych kosztów transportu oraz konieczności dodatkowych wypłat dla pracowników z tytułu nadgodzin ${ }^{51}$.

\section{Sytuacja w przemyśle}

Przemysł na Ziemi Lubuskiej, jak i w reszcie kraju, nieomal w całości został zatrzymany i nie pracował 2 stycznia, wyjątkiem były przedsiębiorstwa branży spożywczej oraz wytwórnie funkcjonujące w ruchu ciągłym. W obu województwach załogi zatrzymanych zakładów w większości skierowano do

50 APZG, UWZG, sygn. 1308, Informacja o skutkach i stopniu ich usunięcia powstałych w wyniku złych warunków atmosferycznych w WPHW Zielona Góra, Zielona Góra, 9 I 1979, b.pag.

51 APZG, UWZG, sygn. 1308, Wojewódzka Spółdzielnia Spożywców „Społem” w Zielonej Górze do Wydziału Handlu i Usług Urzędu Wojewódzkiego w Zielonej Górze, Zielona Góra, 9 I 1979, b.pag.; ibidem, Straty z tytułu nadgodzin koniecznych do zachowania ciągłości handlu i produkcji, b.pag. Jeszcze większe zimowe szkody, prawie $16 \mathrm{mln}$ zł, odnotował Wojewódzki Związek Spółdzielni Rolniczych „Samopomoc Chłopska” w Zielonej Górze, który, oprócz piekarni, masarni i wytwórni wód gazowanych, zarządzał także mieszalniami pasz oraz zakładami produkującymi materiały budowlane (ibidem, Straty spowodowane mrozami w dniach 2-8 I 1979 w produkcji, handlu i inwestycjach, b.pag.). 
odśnieżania $^{52}$. Najbardziej odczuwano przerwy w dostawach prądu oraz brak węgla. Dramatyczne kłopoty przeżywały m.in. Kostrzyńskie Zakłady Papiernicze (KZP) - 2 stycznia posiadany zapas opału miał starczyć tutaj do utrzymania pracy zaledwie do godz. 16.00. Transport $\mathrm{z}$ węglem dla elektrociepłowni KZP, choć wyruszył ze Śląska jeszcze 30 grudnia, utknął na trasie. Ostatecznie, po wyczerpaniu się opału, produkcję w zakładzie wstrzymano ${ }^{53}$.

W kolejnych dniach starano się stopniowo przywracać do pracy poszczególne przedsiębiorstwa. W Gorzowskiem 4 stycznia ruszyło 60\% zakładów produkujących na rynek, dzień później zaś już 80\%, choć nie wszystkie funkcjonowały na pełnych obrotach. Najbardziej energochłonne przedsiębiorstwa podejmowały działalność później, inne, $\mathrm{z}$ uwagi na brak węgla, były w dalszym ciągu unieruchomione, m.in. Barlineckie Przedsiębiorstwo Przemysłu Drzewnego i Zakłady Przetwórstwa Owocowo-Warzywnego w Międzychodzie. 8 stycznia w województwie pracowały już wprawdzie wszystkie zakłady, jednak $30 \% \mathrm{z}$ nich posiadało zapas opału jedynie na dwa do czterech dni ${ }^{54}$.

Druga fala mrozów i śniegu w połowie lutego doprowadziła w Gorzowskiem do podobnych problemów, jak w styczniu. 17 lutego brak węgla zatrzymał produkcję w Nadodrzańskich Zakładach Przemysłu Owocowo-Warzywnego w Dębnie, a dwa dni później z tego samego powodu stanęła ponownie wytwórnia w Międzychodzie (w obu przedsiębiorstwach straty liczono później w dziesiątkach mln zł). Niedostatek opału zagrażał postojem zakładów innych branż. Produkcję zakłócały również poważnie niedobory opakowań (puszek, słoików) w wytwórniach owocowo-warzywnych, a zwłaszcza problemy z odbiorem z poszczególnych firm gotowych towarów i wyrobów kooperacyjnych, których nie było gdzie składowaćs ${ }^{5}$.

${ }^{52}$ Zdarzało się, że na skutek nieznajomości decyzji wielu pracowników stawiło się także do tych zakładów, w których nie przewidziano podjęcia pracy - wówczas odsyłano ich do domu lub zatrudniano przy odśnieżaniu (AAN, KC PZPR, sygn. XII-3814, Informacja nr III/4/79, Warszawa, 2 I 1979, Usuwanie skutków mrozów i opadów śniegu, b.pag.).

53 APG, KW PZPR, sygn. 395, Teleks nr 2. KW Gorzów do Komitetu Centralnego PZPR, Gorzów, 2 I 1979, k. 2. Brak węgla spowodował zatrzymanie produkcji w KZP także 1 marca. Złą sytuację potęgował fakt, że zakładowa elektrociepłownia dostarczała ciepło również kostrzyńskim osiedlom mieszkaniowym, przedszkolom i żłobkom (ibidem, Teleks nr 53. KW Gorzów do Komitetu Centralnego PZPR, Gorzów Wlkp., 1 III 1979, k. 54).

54 APZG, KW PZPR, sygn. 243, Protokół nr 1 wspólnego posiedzenia Egzekutywy Komitetu Wojewódzkiego PZPR i Prezydium WRN w Zielonej Górze z dnia 12 I 1979, k. 7; APG, KW PZPR, sygn. 395, Teleks nr 5. KW Gorzów do Komitetu Centralnego PZPR, Gorzów, 4 I 1979, k. 5; ibidem, Teleks nr 7. KW Gorzów do Komitetu Centralnego PZPR, 5 I 1979, k. 8; ibidem, Teleks nr 14. KW Gorzów do Komitetu Centralnego PZPR, Gorzów, 9 I 1979, k. 15.

55 APG, KW PZPR, sygn. 395, Teleks nr 42. KW Gorzów do Komitetu Centralnego PZPR, Gorzów, 16 II 1979, k. 43; ibidem, Teleks nr 43. KW Gorzów do Komitetu Centralnego PZPR, Gorzów, 17 II 1979, k. 44; por.: AAN, KC PZPR, sygn. XII-3814, Informacja nr III/25/79, Aktualna sytuacja w zakładach produkcyjnych. Niektóre elementy nastrojów społecznych, Warszawa, 9 I 1979, b.pag. 
W Zielonogórskiem 3 stycznia zaczęły działać 22 przedsiębiorstwa, a warunkiem podjęcia pracy przez dany zakład było posiadanie przynajmniej pięciodniowych rezerw węgla oraz zapewnienie niezbędnych dostaw prądu. Jednak nie od razu do przedsiębiorstw zdołali dotrzeć w komplecie ich pracownicy ${ }^{56}$. W poniedziałek 8 stycznia w województwie funkcjonowały już wszystkie zakłady, ale bez wykorzystania całych mocy produkcyjnych; działalności, z uwagi na przerwy w przesyle energii, nie podjęły jedynie Zakłady Produkcji Elementów Budowlanych w Powodowie ${ }^{57}$. W kolejnych dniach w dalszym ciągu największym problemem był opał. 10 stycznia krytycznie małymi rezerwami węgla dysponowały m.in. Lubuskie Zakłady Termotechniczne „Elterma” w Świebodzinie, Żagańskie Huty Szkła w Iłowej, Zakłady Przemysłu Spożywczego w Zielonej Górze, Dolnośląskie Zakłady Metalurgiczne „Dozamet” w Nowej Soli oraz większość zakładów pracy wykorzystujących jako paliwo węgiel brunatny, m.in. Nowosolska Fabryka Nici „Odra” czy Zakłady Przemysłu Wełnianego w Lubsku. Nieco lepsza sytuacja pod tym względem (rezerwy opału na więcej niż dwa tygodnie pracy według stanu z 10 stycznia) panowała natomiast w Zaodrzańskich Zakładach Przemysłu Metalowego „Zastal”, Lubuskiej Fabryce Zgrzeblarek Bawełnianych „Falubaz” oraz Krośnieńskich Zakładach Metalowych „Kromet”58.

Największe szkody ponosiły przede wszystkim duże przedsiębiorstwa, ale straty nie ominęły także drobniejszych zakładów. Przykład stanowić mogą jednostki podległe Zarządowi Regionalnemu Związku Spółdzielni Inwalidów w Zielonej Górze: Spółdzielnia Inwalidów „Powstaniec” w Karpicku z powodu odcięcia energii elektrycznej w dniach 31 grudnia 1978 - 2 stycznia 1979 r. odnotowała straty w wysokości 120 tys. zł, a Spółdzielnia Inwalidów Niewidomych „Piast” z Sulechowa musiała wypłacić ok. 0,5 mln zł pracownikom, którzy nie przystąpili

56 APZG, KW PZPR, sygn. 243, Protokół nr 1 wspólnego posiedzenia Egzekutywy Komitetu Wojewódzkiego PZPR i Prezydium WRN w Zielonej Górze z dnia 12 I 1979, k. 7.

57 Szacowano, że w pierwszej dekadzie stycznia w Zielonogórskiem nie wykonano produkcji na sumę $750 \mathrm{ml} \mathrm{zł,} \mathrm{z} \mathrm{czego} \mathrm{najwięcej} \mathrm{przypadało} \mathrm{na} \mathrm{przemysł} \mathrm{(550} \mathrm{mln} \mathrm{zł)} \mathrm{oraz} \mathrm{budownictwo}$ $(108 \mathrm{mln})$, natomiast straty w środkach trwałych wyniosły w tym czasie ok. $18 \mathrm{mln}$ zł (APZG, KW PZPR, sygn. 243, Informacja o sytuacji społeczno-gospodarczej w województwie zielonogórskim wynikłej z ostrego ataku zimy w dniach od 30 XII 1978 r. do dnia 9 I 1979 r., k. 78; ibidem, Protokół nr 1 wspólnego posiedzenia Egzekutywy Komitetu Wojewódzkiego PZPR i Prezydium WRN w Zielonej Górze z dnia 12 I 1979, k. 8).

58 APZG, KW PZPR, sygn. 243, Informacja o sytuacji społeczno-gospodarczej w województwie zielonogórskim wynikłej z ostrego ataku zimy w dniach od 30 XII 1978 r. do dnia 9 I 1979 r., k. 78; ibidem, Protokół nr 1 wspólnego posiedzenia Egzekutywy Komitetu Wojewódzkiego PZPR i Prezydium WRN w Zielonej Górze z dnia 12 I 1979, k. 5-6, 8. W najgorszej sytuacji opałowej w Zielonogórskiem (stan na 10 stycznia) znajdowały się przedsiębiorstwa szklarskie, meblarskie, ceramiki budowlanej, a także zakłady przemysłu lekkiego pracujące $\mathrm{z}$ wykorzystaniem węgla, pożyczanego z dnia na dzień, z innych jednostek (ibidem, k. 6). 
do pracy. Większość spółdzielczych wytwórni w Zielonogórskiem nie miała też szans na wykonanie miesięcznych planów produkcji w styczniu 1979 r. ${ }^{59}$

Komplikacje przemysłu wynikały nie tylko z powodu braku opału czy prądu. Coraz większym problemem stawało się zakłócanie rytmu dostaw surowców, różnego rodzaju materiałów i podzespołów. Na przykład z województwa gorzowskiego informowano 9 stycznia, że w zakładach metalowych występują niedobory acetylenu, do przedsiębiorstw odzieżowych nie dostarczano tkanin dla bieżącej produkcji, w jednostkach wytwarzających stolarkę budowlaną kończyły się zapasy tarcicy. Zakłady Włókien Chemicznych "Chemitex-Stilon” w Gorzowie Wlkp., zatrudniające 10 tys. osób, musiały znacznie ograniczyć wytwarzanie, gdyż nie otrzymały kaprolaktamu, którego dostawcą były Zakłady Azotowe „Puławy” (złożono nawet w tej sprawie skargę do Ministerstwa Przemysłu Chemicznego). Z kolei do innego gorzowskiego przedsiębiorstwa - Zakładów Mechanicznych „Ursus” - nie nadeszły konieczne do produkcji pręty walcowane i odkuwki. Niedostatki bądź zupełne braki materiałów i surowców z powodu zimy dotknęły też m.in. Zakłady Przemysłu Maszynowego Leśnictwa „Gomad” (blachy), Gorzowskie Zakłady Mechanizacji Budownictwa "Zremb” (drut spawalniczy) oraz Zakłady Przemysłu Jedwabniczego „Silwana” (przędza wiskozowa) ${ }^{60}$. W Zielonogórskiem w Nadodrzańskich Zakładach Przemysłu Lniarskiego „Odra” w Nowej Soli występowały poważne niedobory podstawowych materiałów do produkcji - lnu i bawełny. Z kolei Lubuskie Zakłady Drobiarskie „Poldrób” w Nowej Soli zostały zatrzymane z powodu braku surowców aż do 15 lutego $^{61}$.

\section{Kłopoty w rolnictwie}

Sile mrozy i śnieg uderzyły dotkliwie w produkcję rolną. W niedogrzanych wiejskich budynkach, wylęgarniach i fermach drobiu oraz w dużych gospodarstwach hodowlanych zwierzęta padały tysiącami. Olbrzymie szkody odnotowano w produkcji szklarniowej. Poważnie spadła mleczność krów, co skutkowało niedoborami masła, śmietany i serów. Z wielu województw informowano o trudnościach w skupie, zwłaszcza mleka, ale także zwierząt rzeźnych, którego poziom w pierwszym tygodniu 1979 r. w skali ogólnopolskiej obniżył się o blisko 40\%

59 APZG, UWZG, sygn. 1308, Do Obywatela Dionizego Gajnego, wicewojewody zielonogórskiego. Zielona Góra, 10 I 1979, [pismo] b.pag.

60 APG, KW PZPR, sygn. 395, Teleks nr 14. KW Gorzów do Komitetu Centralnego PZPR, Gorzów, 9 I 1979, k. 15; ibidem, Teleks nr 18. KW Gorzów do Komitetu Centralnego PZPR, 17 I 1979, k. 19; ibidem, Teleks nr 25. KW Gorzów do Komitetu Centralnego PZPR, 26 I 1979, k. 26. Dostawcami prętów walcowanych były Huta Baildon z Katowic oraz Huta Warszawa, skuwki zaś produkowano w Zakładach Kuzienniczych i Maszyn Rolniczych „Agromet” w Jaworze (ibidem).

${ }^{61}$ APZG, Komitet Miejsko-Gminny PZPR w Nowej Soli, sygn. 59, Notatka z przeprowadzonych rozmów z Egzekutywą Komitetu Miejskiego PZPR w Nowej Soli w dniu 26 I 1979, k. 8. 
w stosunku do analogicznego okresu roku ubiegłego. Na niektórych obszarach ucierpiały również uprawy zbóż ozimych ${ }^{62}$.

Na Ziemi Lubuskiej ciężkie warunki panowały zwłaszcza w 14 fermach bydła mlecznego, stanowiących część Państwowych Gospodarstwach Rolnych - sześć takich ferm działało $\mathrm{w}$ województwie zielonogórskim, a osiem w gorzowskim. Temperatura w budynkach tych przedsiębiorstw na początku stycznia spadła do kilku stopni poniżej zera (szczególnie w Gorzowskiem), co zagrażało wyposażeniu - przewodom rur wodociągowych oraz dojarek. Najdotkliwsze były wyłączenia prądu, powodujące unieruchomienie dojarek mechanicznych. Konsekwencje tego łatwo sobie wyobrazić, jeśli weźmie się pod uwagę, że w każdej z ferm znajdowało się 700 i więcej krów, a dzienny udój w zwykłych warunkach wynosił średnio od 8 do 10 tys. litrów mleka. Jedynym rozwiązaniem był montaż agregatów prądotwórczych w tych fermach, które ich nie posiadały. I tak np. z Łużyckiego Kombinatu Rolnego PGR w Bieniowie przetransportowano agregat prądotwórczy do fermy bydła mlecznego w Czciradzu, należącej z kolei do Żagańskiego Kombinatu Rolnego PGR. Wiele wysiłku wymagał również transport mleka w cysternach z poszczególnych jednostek z uwagi na utrudniony dojazd zaśnieżonymi drogami. Dotyczyło to przede wszystkim gospodarstw w Wawrowie i Przytocznej (gorzowskie) oraz w Staropolu, Bukowie, Czciradzu i Piotrowie (zielonogórskie). Podobne problemy dotyczyły także dowozu pasz ${ }^{63}$.

Ostra zima zakłócała nie tylko pracę ferm bydła mlecznego. W województwie gorzowskim między 29 grudnia a 7 stycznia z powodu wyłączeń energii i mrozów odnotowano stratę ok. 900 sztuk prosiąt i warchlaków, 170 sztuk cieląt oraz ponad 150 sztuk jagniąt. Z kolei na fermach drobiu padło aż 25 tys. piskląt i brojlerów o łącznej wartości ok. 3,5 mln zł. Zakłady mięsne nie odbierały trzody chlewnej i bydła przeznaczonego na rzeź. Do punktów skupu oddano w tym czasie mniej o 280 tys. litrów mleka, co od razu odbiło się na rynku (nie uzyskano produkcji o wartości 1,5 mln zł); w trzydziestu punktach skupu w Gorzowskiem, w gminach Choszczno, Bogdaniec i Lubiszyn mleko zamarzło w basenach. W PGR-ach, spółdzielniach produkcyjnych i kółkach rolniczych brakowało węgla ${ }^{64}$.

${ }^{62}$ Za: M. Zaremba, Wywrotowa zima..., s. 63; AAN, KC PZPR, sygn. XII-3814, Informacja nr III/21/79, Warszawa, 8 I 1979, Usuwanie skutków mrozów i opadów śniegu. Aktualna sytuacja w kraju, b.pag.

63 Ziemia Lubuska w okowach zimy, „Gazeta Lubuska” 3 I 1979, nr 2. W PGR-ach w Gorzowskiem agregatów prądotwórczych brakowało (przynajmniej 50 szt.), te zaś, którymi dysponowano, były w znacznej mierze wyeksploatowane (APG, KW PZPR, sygn. 395, Teleks nr 30. KW Gorzów do Komitetu Centralnego PZPR, 1 II 1979, k. 31).

${ }^{64}$ APG, KW PZPR, sygn. 395, Teleks nr 11. KW Gorzów do Komitetu Centralnego PZPR, 8 I 1979, k. 13; ibidem, Teleks nr 4. KW Gorzów do Komitetu Centralnego PZPR, Gorzów, 3 I 1979, k. 4; AAN, KC PZPR, sygn. XII-3814, Informacja nr III/14/79, Warszawa, 5 I 1979, Usuwanie skutków mrozów i opadów śniegu, b.pag. 
Równie ciężkie chwile na początku stycznia przeżywało rolnictwo w Zielonogórskiem. Skup mleka w tym czasie osiągał w całym województwie zaledwie 70\% normalnego poziomu. Wojewódzka Spółdzielnia Mleczarska jedynie w okresie od 30 grudnia do 5 stycznia oszacowała szkody na 4,5 mln zł, które wystąpiły w punktach skupu mleka i przetwórstwa, odnosiły się do ograniczenia asortymentu produkcji, zniszczenia opakowań oraz kosztów transportu ${ }^{65}$. Najtrudniejsza sytuacja dotyczyła jednak produkcji zwierzęcej, zwłaszcza w PGR-ach i spółdzielniach produkcyjnych, gdzie wyłączenia prądu przyniosły największe straty: tylko do 10 stycznia padło tutaj 1170 prosiąt i warchlaków oraz 112 cieląt. Sytuację poprawiło nieco skierowanie do tych jednostek dodatkowych agregatów prądotwórczych oraz zorganizowanie dowozu przez straż pożarną i wojsko wody beczkowozami (PGR-y zobowiązano, żeby do przewozu mleka wykorzystać nowe cysterny innego przeznaczenia). Brak energii przyniósł poważne szkody w uprawach szklarniowych, jak np. w Spółdzielni Produkcyjnej w gminie Wolsztyn, gdzie dodatkowo zniszczeniu uległy obiekty tego gospodarstwa ${ }^{66}$.

Omawiając skutki zimy w rolnictwie, warto też wspomnieć o mniej znanym problemie szkód, jakie mrozy, a zwłaszcza śnieg, spowodowały w kompleksach leśnych. Jest to o tyle istotne, że oba lubuskie województwa zaliczały się do jednych z najbardziej zalesionych w kraju. Straty występowały na skutek wystąpienia ogromnej liczby śniegołomów, czyli drzew, których konary połamały się pod ciężarem setek kilogramów zlodowaciałego lub mokrego śniegu. Jedynie w trzech nadleśnictwach województwa gorzowskiego: Drawnie, Głusku i Bierzwniku zimowe ubytki w drzewostanie oceniano wstępnie na 400 tys. $\mathrm{m}^{367}$.

\section{Pozostałe skutki ataku zimy}

Zawieszenie zajęć w szkołach po nowym roku nie oznaczało, że placówki oświatowe w całym kraju były zamknięte przez taki sam okres. Rozstrzygnięcia w tej kwestii należały do poszczególnych wojewodów w zależności od warunków pogodowych i przygotowania obiektów szkolnych. W Gorzowskiem zdecydowano o przedłużeniu przerwy w zajęciach lekcyjnych do 10 stycznia. Oczywiście głównym powodem były wciąż nieusunięte skutki awarii ogrzewania w wielu

${ }^{65}$ APZG, UWZG, sygn. 1308, Wojewódzka Spółdzielnia Mleczarska do Urzędu Wojewódzkiego w Zielonej Górze, Zielona Góra, 9 I 1979, b.pag.

${ }^{66}$ AAN, KC PZPR, sygn. XII-3814, Informacja nr III/6/79, Warszawa, 3 I 1979, Usuwanie skutków mrozów i opadów śniegu, b.pag.; APZG, KW PZPR, sygn. 243, Protokół nr 1 wspólnego posiedzenia Egzekutywy Komitetu Wojewódzkiego PZPR i Prezydium WRN w Zielonej Górze z dnia 12 I 1979, k. 10.

${ }^{67}$ APG, WRN, sygn. 8, Protokół nr XVII/79 przebiegu sesji Wojewódzkiej Rady Narodowej w Gorzowie Wlkp. odbytej w dniu 27 VI 1979, k. 240. 
budynkach szkół, brak opału, a także kłopoty z dojazdami dzieci na zajęcia, zwłaszcza w mniejszych miejscowościach. Jeszcze 6 stycznia w budynkach szkolnych w Witnicy, Santoku, Koszęcinie i Zwierzynie nie zdołano uporać się ze wszystkimi uszkodzeniami instalacji grzewczych ${ }^{68}$. Nieco lepiej wyglądała sytuacja w szkołach województwa zielonogórskiego, gdzie nauka została wznowiona 8 stycznia, a zapasy węgla $\mathrm{w}$ przyszkolnych kotłowniach pozwalały na $\mathrm{w}$ miarę normalne funkcjonowanie placówek w kolejnych dniach ${ }^{69}$. Nawrót zimy w połowie lutego spowodował, że w Gorzowskiem, szczególnie w jego północnych rejonach, do szkół przez kilka dni nie docierały setki dzieci. Trudności były też z odwożeniem dzieci do domów, jak choćby 15 lutego, kiedy uczniowie zbiorczej szkoły gminnej w Nowogródku Pomorskim zostali uwięzieni w swojej placówce na dwa dni ${ }^{70}$.

Zimowe perturbacje nie ominęły instytucji kultury czy sportu. Przykładowo według informacji Wydziału Kultury i Sztuki Urzędu Wojewódzkiego w Zielonej Górze Filharmonia Zielonogórska im. Tadeusza Bairda z powodu niedogrzania musiała zawiesić działalność artystyczną między 2 a 5 stycznia - temperatura na sali koncertowej wahała się w granicach $8-10^{\circ} \mathrm{C}$, co oczywiście uniemożliwiało przeprowadzanie prób i koncertów. Również pomieszczenia zielonogórskiej Wojewódzkiej i Miejskiej Biblioteki Publicznej im. Cypriana Norwida były niedogrzane z powodu małej ilości, a także niskiej jakości opału (brykietu i węgla brunatnego). Temperatura w pomieszczaniach nie przekraczała $14^{\circ} \mathrm{C}$, co wywołało konieczność skrócenia czasu pracy czytelni i wypożyczalni o 2 godziny $^{71}$. Z kolei w Ośrodku Pięcioboju Nowoczesnego i Jeździectwa w Drzonkowie popękały od mrozu rury wodociągowe, zamarzły zapasy ziemniaków oraz padło z zimna kilka sztuk owiec, a w budynkach Wojewódzkiego Ośrodka Sportu i Rekreacji niskie temperatury uszkodziły centralne ogrzewanie, rury wodociaggowe i instalacje elektryczne. Straty nie ominęły obiektów Lubuskiego Przedsiębiorstwa Gospodarki Turystycznej „Lubtour”, gdzie odnotowano awarie instalacji centralnego ogrzewania i wodno-kanalizacyjnej, jednak bardziej dotkliwa była utrata dochodu z powodu ograniczenia działalności w obiektach noclegowych i gastronomicznych oraz odwołanie imprez zorganizowanych przez Centrum Usług Turystycznych ${ }^{72}$.

68 AAN, KC PZPR, sygn. XII-3814, Informacja nr III/21/79, Warszawa, 8 I 1979, Usuwanie skutków mrozów i opadów śniegu. Aktualna sytuacja w kraju, b.pag.; ibidem, Informacja nr III/24/79, Warszawa, 9 I 1979, Rozpoczęcie zajęć szkolnych, b.pag.; APG, KW PZPR, sygn. 395, Teleks nr 11. KW Gorzów do Komitetu Centralnego PZPR, 8 I 1979, k. 12.

${ }^{69}$ APZG, KW PZPR, sygn. 243, Protokół nr 1 wspólnego posiedzenia Egzekutywy Komitetu Wojewódzkiego PZPR i Prezydium WRN w Zielonej Górze z dnia 12 I 1979, k. 10; AAN, KC PZPR, sygn. XII-4263, Informacja o aktualnej sytuacji w województwie zielonogórskim w dniu 8 I 1979, b.pag.

70 APG, KW PZPR, sygn. 395, Teleks nr 36. KW Gorzów do Komitetu Centralnego PZPR, Gorzów, 14 II 1979, k. 37; ibidem, Teleks nr 37. KW Gorzów do Komitetu Centralnego PZPR, Gorzów, 15 II 1979, k. 38.

${ }^{71}$ APZG, UWZG, sygn. 1308, Do Wojewódzkiej Komisji Planowania, Zielona Góra, 9 I 1979, b.pag.

72 APZG, UWZG, sygn. 1308, Sprawa strat poniesionych w wyniku zimy, Zielona Góra, 9 I 1979, b.pag. 
Dodatkową konsekwencją „zimy stulecia” na Ziemi Lubuskiej było niebezpieczeństwo powodziowe. W Zielonogórskiem na przełomie grudnia i stycznia na rzece Bóbr utworzył się prawie ośmiokilometrowy zator lodowy, zalanie groziło okolicom Żagania i samemu miastu. Z brzegów wystąpił dopływ Bobru - Czerna Wielka, a jej wody dostały się do części piwnic w budynkach przy ul. Feliksa Dzierżyńskiego (obecnie ul. Dworcowa) oraz Wincentego Pstrowskiego (obecnie ul. Włókniarzy). Zalana została także część urząazeń technicznych w niżej położonych obiektach przemysłowych Żagania - m.in. w Żagańskich Zakładach Przemysłu Wełnianego oraz Zakładach Zmechanizowanego Sprzętu Domowego „Polar”. Sytuację opanowano dzięki pomocy saperów ze Śląskiego Okręgu Wojskowego, którzy z użyciem ładunków wybuchowych, zrzucanych z pokładu śmigłowca, udrożnili rzekę. Akcję prowadzono w szczególnie niesprzyjających warunkach i przy utrudnionym dostępie do rzeki. Jej ubocznym efektem, o czym oficjalnie nie informowano, stały się znaczne straty w postaci stłuczonych od wybuchów szyb w oknach okolicznych domów, które, w obliczu bardzo niskich temperatur, wymagały natychmiastowego zabezpieczenia ${ }^{73}$.

Zagrożenie powodzią, choć w mniejszym zakresie, wystąpiło także w Gorzowskiem. 7 stycznia w rejonie Drezdenka poziom wody na Noteci przekroczył o $26 \mathrm{~cm}$ stan alarmowy, a 10 stycznia zaistniała realna groźba przerwania wałów, które już przesiąkały, zwłaszcza w gminach Drezdenko, Zwierzyń, Stare Kurowo i Santok. 15 stycznia również na Odrze w Słubicach poziom alarmowy został przekroczony o pół metra. Tego samego dnia na Warcie w Gorzowie Wlkp. stan alarmu został z kolei przewyższony o $23 \mathrm{~cm}$, jednak w kolejnych dniach sytuacja zaczęła się stabilizować ${ }^{74}$.

\section{Zamiast podsumowania}

Prasa, radio i telewizja na początku stycznia 1979 r. komunikowały wprawdzie szeroko o dramatycznej sytuacji w kraju, jednak cenzura - jak wspominał Mieczysław Rakowski - otrzymała instrukcję, aby do obiegu dopuszczać wyłącznie te materiały, które wychwalały bohaterstwo i poświęcenie ludzi pracy w walce z żywiołem. Próżno było więc szukać w gazetach doniesień o śmiertelnych ofiarach mrozów,

\footnotetext{
73 APZG, KW PZPR, sygn. 243, Protokół nr 1 wspólnego posiedzenia Egzekutywy Komitetu Wojewódzkiego PZPR i Prezydium WRN w Zielonej Górze z dnia 12 I 1979, k. 10; AAN, KC PZPR, sygn. XII-4265, Informacja o aktualnej sytuacji w województwie zielonogórskim, Zielona Góra, 2 I 1979, b.pag.; Wojsko przeciw zimie, „Polityka” 3 II 1979, nr 5, s. 9; Ziemia Lubuska w okowach zimy, „Gazeta Lubuska” 3 I 1979, nr 2.

74 APG, KW PZPR, sygn. 395, Teleks nr 10. KW Gorzów do Komitetu Centralnego PZPR, 7 I 1979, k. 11; ibidem, KW PZPR, sygn. 638, Aktualna sytuacja w rolnictwie. Sytuacja na rzekach województwa wg stanu na dzień 15 I 1979, k. 15.
} 
a tylko do 2 stycznia miało ich być 14 (liczba ta jest mało wiarygodna, gdyż jedynie w samej Bydgoszczy zamarzło w tym czasie pięć osób) ${ }^{75}$; sporadycznie do środków masowego przekazu przenikały informacje o transportowaniu przez karetki pacjentów z odmrożeniami twarzy albo rąk, jak w województwach ostrołęckim i siedleckim. Dość zdawkowo informowano o rozmiarach czy skutkach różnych awarii, a tym bardziej o takich faktach jak np. samowolnych przejęciach przez niektóre przedsiębiorstwa państwowe węgla na eksport, czekającego w wagonach w porcie gdańskim ${ }^{76}$. Nie podawano również do publicznej wiadomości raportów Centrali Zbytu Węgla, która sygnalizowała, „iż są przypadki rozdysponowania $\mathrm{w}$ terenie pociągów z węglem na inne cele, niezgodne z przeznaczeniem, co dezorganizuje sterowanie dostawami"77.

Tymczasem panowało powszechne przekonanie, również wśród członków partii, że gwałtowny atak zimy ujawnił całą masę słabych ogniw polskiego systemu ekonomicznego, głównie w sferze transportu, energetyki, ciepłownictwa i branży komunalnej. Równie rażące były zaniedbania władz w zapewnieniu wystarczających rezerw, brakoróbstwo w projektowaniu i wykonawstwie budynków mieszkalnych oraz chaos organizacyjny. Krytykujący ówczesną sytuację stwierdzali, że wystarczyło zaledwie kilka dni ostrych mrozów i śniegu, żeby sparaliżować całą gospodarkę narodową. Pytano z goryczą, dlaczego Polska, będąca potentatem $w$ wydobyciu węgla, podczas zimy stulecia cierpiała na jego braki ${ }^{78}$. Pewien robotnik z Głogowa w liście do KC ze stycznia oceniał sarkastycznie: „Potrafimy zdobywać kosmos [w kontekście niedawnego lotu Mirosława Hermaszewskiego R.S.], ale nie jesteśmy w stanie zabezpieczyć ludziom ciepła w mieszkaniach. Czy potrzeba wielkiego filozofa aby przewidzieć, że w zimie może być śnieg i zawieja [...]?”79. Autor innego listu pisał z kolei: „Ja oraz wszyscy moi znajomi z miejsca zamieszkania i pracy stan ten potraktowaliśmy jako szczyt bałaganu i braku poczucia odpowiedzialności kierowniczej kadry administracji gospodarczej za interes społeczny i losy kraju" 80 .

${ }^{75}$ M.F. Rakowski, op. cit., s. 10; M. Zaremba, Wywrotowa zima..., s. 61-62. Oprócz zgonów wywołanych bezpośrednio zimnem, należałoby jeszcze uwzględnić te, do których doszło na skutek niedojechania karetek pogotowia, odłożenia zaplanowanych w szpitalach operacji, wychłodzenia się osób starszych, większej zapadalności dzieci na choroby układu oddechowego, zaczadzenia, wypadków na kolei (np. sześć osób poniosło śmierć w wyniku zaczadzenia w pociągu relacji Berlin - Moskwa) oraz na drogach (za: ibidem, s. 61-62).

${ }_{76}$ M.F. Rakowski, op. cit., s. 10; M. Wesołowska, op. cit., s. 3.

77 AAN, KC PZPR, sygn. XII-4260, Informacja o sytuacji w dniu 3 I 1979 r. godz. 18.00, Warszawa, 3 I 1979, b.pag.

78 APG, KW PZPR, sygn. 395, Teleks nr 14. KW Gorzów do Komitetu Centralnego PZPR, Gorzów, 9 I 1979, k. 11.

79 Cyt. za: R. Domke, Problemy społeczne Polaków w świetle analiz Biura Listów KC PZPR w latach siedemdziesiątych XX wieku, „Pamięć i Sprawiedliwość” 2011, nr 1, s. 365.

${ }^{80}$ M. Zaremba, Wywrotowa zima..., s. 63. 
Władze, świadome niezadowolenia i społecznego zmęczenia zimowymi trudnościami, śledziły pilnie panujące wówczas nastroje. Odnotowywano więc, że wiele wypowiedzi z tego czasu miało być agresywnych i „szkalujących partię”, krytykujących „ryzykowną politykę gospodarczą”, „pracę bez niezbędnych zapasów” oraz niedowład organizacyjny ${ }^{81}$. Zabrakło jednocześnie szerszych analiz przyczyn powstałej sytuacji czy publicznie stawianych pytań o nieprzygotowanie państwa na takie warunki. A było to tym bardziej istotne, że „paraliż kraju”, jak ironicznie pisała Iwona Kurz, przydarzył się „dziesiątej gospodarczej potędze” świata, a „klęska żywiołowa" nie tyle była zdarzeniem, ile w wyniku nieustępliwości zimy (co nie do końca było winą rządzących, lecz stało się ich karą) i nieustającej nieudolności władzy - stanem trwałym, demonstrując systemowy charakter braków i zaniedbań ${ }^{82}$.

\section{'On the Front Line - Road and Railroad Workers, Power Engineers and the Army'. The So-Called 1979 'Winter of the Century' on the Example of the Lubusz Land (Summary)}

The article deals with the so-called 1979 'Winter of the Century', which coincided with the end of Edward Gierek's rule in the Polish People's Republic and aggravated the economic crisis that had been growing for a long time. The effects of above-average snowfall and severe frost, which hit Poland in the first weeks of 1979, are presented on the example of the Lubusz Land, but in a broad national context. The author analyses the conditions in the country and the region in various fields of economic and social life: communication and transport, the energy and heating systems, trade and supply to the population, as well as in relation to industrial and agricultural problems. The then authorities' incompetence was emphasised resulting from political system weaknesses, leading to numerous failures and organisational chaos. Considering the extent of the difficulties caused by the winter weather at that time, it is probably no exaggeration to say that it hastened the end of the rule of Gierek' team, which took place less than two years later.

\section{Bibliografia \\ (wybór)}

\section{Pamiętniki, wspomnienia}

Rakowski M.F., Dzienniki polityczne 1979-1981, t. 7, Warszawa 2004

Rolicki J., Edward Gierek. Przerwana dekada. Wywiad rzeka, Warszawa 1990

Sieczkowski G., Zima stulecia. Portret pamięciowy kataklizmu, Warszawa 2017

\section{Opracowania}

Jarosz D., Pierwsza powojenna „zima stulecia” w Polsce. Wybrane konteksty, w: Od powietrza, głodu, ognia i wojny... Klęski elementarne na przestrzeni wieków, red. T. Głowiński, E. Kościk, Wrocław 2013

81 Za: M. Zaremba, Zimno, ciepło, goraco..., s. 137-138.

${ }^{82}$ Za: I. Kurz, Pogoda. Zima stulecia w stuleciu zim, „dwutygodnik.com”, https://www.dwutygodnik. com/artykul/4720-pogoda-zima-stulecia-w-stuleciu-zim.html (dostęp: 12 XI 2020). 
Kruk B., „Pamiętam był ogromny mróz...”. Zimowe zmagania Polskich Kolei Państwowych po II wojnie światowej, w: Od powietrza, głodu, ognia i wojny... Klęski elementarne na przestrzeni wieków, red. T. Głowiński, E. Kościk, Wrocław 2013

Wilk H., Zima stulecia - zmagania $z$ żywiołem 1962/1963, w: Od powietrza, głodu, ognia i wojny... Klęski elementarne na przestrzeni wieków, red. T. Głowiński, E. Kościk, Wrocław 2013

Zaremba M., Zimno, ciepło, goraco, w: Dekada Gierka. Polska i Polacy między Grudniem '70 a Sierpniem '80, „Polityka. Pomocnik Historyczny”' 14/2010

Zaremba M., Wywrotowa zima, „Polityka” 17 I 2009, nr 3

Robert Skobelski, doktor habilitowany, profesor Uniwersytetu Zielonogórskiego, dyrektor Instytutu Historii UZ. Autor lub współautor kilku monografii, m.in. Polityka PRL wobec państw socjalistycznych w latach 1956-1970. Wspótpraca - napięcia - konflikty (2010), Powiew demokracji. Wybory do Sejmu PRL z 1957 roku (2021). Publikował m.in. w „Kwartalniku Historycznym”, „Dziejach Najnowszych”, „Pamięci i Sprawiedliwości” i „Przeglądzie Zachodnim”. Jego zainteresowania badawcze koncentrują się wokół społecznej, politycznej i gospodarczej historii PRL oraz dziejów regionu lubuskiego po $1945 \mathrm{r}$.

Kontakt: r.skobelski@ih.uz.zgora.pl 